\title{
SHARED SERVICE CENTRE - CASE STUDY HENKEL GMBH
}

\author{
Lidija Barjaktarović, \\ Nikola Stefanović, \\ Miloš Đukanović
}

\author{
${ }^{1}$ Singidunum University, \\ Belgrade, Serbia \\ ${ }^{2}$ Henkel Srbija d.o.0.
}

\begin{abstract}
:
The subject of the research is Shared Service Centre (SSC) established by Henkel GmbH. Henkel $\mathrm{GmbH}$ is the leader in SSC, and belongs to the group of companies which has started automatized activities in it. The aim of this article is to emphasize that permanent improvement of business performance with fulfilling customer requests is a precondition for further development of any company. The main hypothesis of the research is that SSC improved profitability of the company. It is tested and confirmed on EBIT margin in \% of Henkel GmbH. The case study is based on interviews and presentations of Henkel's CFOs in the period from 2003 to 2017, and the relevant data announced in annual reports of the company. However, Henkel $\mathrm{GmbH}$ will have new challenges with appliance of a new strategy, in order to support their vision to create sustainable value. One of them is to accelerate digitalization, especially in SSC.
\end{abstract}

Keywords:

shared service centre, cost, efficiency, optimization, Henkel, finance, CFO.

\section{INTRODUCTION}

The contemporary market terms and conditions required flexible company's approach in order to survey. Profit is one of the key drivers for all legal entities, and possibilities for cost decrease are always important topics, including adjustment to the digitalization development and improved data security. Shared Service Centre (SSC) can be defined as a business model that optimizes resources availability through organization, in order to standardize processes, decrease costs and improve (internal and external) customer-service satisfaction. Accordingly, effective implementation of SSC needs restructuring of organization i.e. duties and responsibilities between different company's departments, SSC and customers. Moreover, dilemmas with introducing SSC which management of the company has, are: (1) what are the differences between centralized and decentralized business model? (2) What are the differences compared to the classic back office? (3) What are the differences compared to outsourcing? The answer is that SSC has a clear focus on processes (delivery and performance), best sharing practices, improvement and structuring of customer relationship processes. (Deloitte, 2011) ${ }^{1}$ Outsourcing can be considered for any non-core service (Searle, 2013). ${ }^{2}$ Generally, in practice companies can make different decisions: to establish own SSC, to outsource SSC or to have mixed structure (such Henkel GmbH has).

Accordingly, a subject of the research is shared service centre which is established by Henkel $\mathrm{GmbH}$. The aim of this article is to emphasize that permanent improvement of business performance with fulfilling customer requests is a precondition for further development of any company. The main hypothesis of the research is that SSC improved profitability of the company. It will be tested on EBIT margin in \% of Henkel GmbH.

1 Deloitte (2011) Shared Service Hand Book - Hit the Road, Deloitte

2 Searle P. (2013) What are Shared Services Best Practices? Chazey Partners 
The research consists of five chapters including introduction and conclusion. The second chapter represents relevant literature review for the research. Within the third part, a methodology is presented. Results of the research are presented in the fourth chapter. The conclusion is presented within the last chapter.

\section{LITERATURE REVIEW}

SSC operating model is usually built on three pillars: people, process and technology. Employees' skills are relevant for the standardization of processes, and their permanent improvement, with a final aim of digitalizing it as much as possible. Those activities will result in a decreased level of cost, efficiency and effectiveness improvement, and a higher level of customer satisfaction.

PwC did a survey in 2008, regarding the major change drivers, benefit and barriers in implementing SSC. Accordingly, CFO's stressed that major: change driver is a cost reduction; benefit is cost savings, the lack of senior management sponsorship and lack of communication. According to Covil and Gurmeet $(2013)^{3}$ the best practices for implementing SSC include the following parameters: process to target, location, and technical consideration, SS Implementation and managing implementation risks. Struhar $(2015)^{4}$ emphasizes that five characteristics of the best SSC are: think globally from the start, consistently expand the function's scope and scale, use 'global process owners' to standardize processes, move rules-based work to low cost regions, and invest in training and recognize the importance of their employees.

Furthermore we will consider Covil and Gurmeet $(2013)^{5}$ parameters for implementing SSC. In terms of a process to target it is important to identify which functions and processes can be transferred to SSC. Usually common SS functions (table 1) are: finance, human resources, information technology, supply chain \& procurement, and corporate affairs \& legal.

Table 1. Common SS Functions

\begin{tabular}{|c|c|c|c|}
\hline Functions & & Common SS Functions & \\
\hline Finance & $\begin{array}{l}\text { General Ledger } \\
\text { Accounts Payable } \\
\text { Internal Audit }\end{array}$ & $\begin{array}{l}\text { Purchasing } \\
\text { Accounts Receivable } \\
\text { Insurance }\end{array}$ & $\begin{array}{l}\text { Tax Compliance } \\
\text { Cash management } \\
\text { Foreign Exchange }\end{array}$ \\
\hline Human Resources & $\begin{array}{l}\text { Payroll processing } \\
\text { Compensation }\end{array}$ & $\begin{array}{l}\text { Benefits admiration } \\
\text { Commission and bonuses }\end{array}$ & $\begin{array}{l}\text { Training } \\
\text { Employee data } \\
\text { management }\end{array}$ \\
\hline Information Technology & $\begin{array}{l}\text { Standards } \\
\text { Technology Development }\end{array}$ & $\begin{array}{l}\text { Application development } \\
\text { Application maintenance }\end{array}$ & $\begin{array}{l}\text { Hardware \& } \\
\text { Software acquisition } \\
\text { Software license management }\end{array}$ \\
\hline Supply Chain \&Procurement & $\begin{array}{l}\text { Inventory management } \\
\text { Distribution management }\end{array}$ & $\begin{array}{l}\text { Logistics } \\
\text { Purchase management }\end{array}$ & $\begin{array}{l}\text { Database management } \\
\text { Order management }\end{array}$ \\
\hline Corporate Affairs \& Legal & $\begin{array}{l}\text { Media Relations } \\
\text { Litigation Support }\end{array}$ & $\begin{array}{l}\text { Communication } \\
\text { Regulatory } \\
\text { Compliance }\end{array}$ & $\begin{array}{l}\text { Travel Coordination } \\
\text { Environment, Health \& } \\
\text { Safety Audits }\end{array}$ \\
\hline
\end{tabular}

Source: (Covil and Gurmeet, 2013 / based on Industry survey \& Research: Respondents of the survey included more than 100 organizations that are using SSC)

According to the same survey (Covil and Gurmeet, 2013) the percentage of business processes that can be moved to SSC are: Finance (93\%), Human Resources (60\%), Information Technology (48\%), Supply Chain \&Procurement (47\%), Sales \& Marketing Support (26\%), Real Estate \& Facilities (23\%) and Legal (19\%). Furthermore, Deloitte's global survey $(2011)^{7}$ of 270 companies: 1$)$ confirmed that there is a very high level of Finance and HR process split (Appendix 1); 2) recorded that there were evident changed role of Finance of existence SSC, where the focus was on business partnering and managing business risk. Furthermore, a changing role of Finance is important in implementing SSC in the company (Seal and Herbert, 2013). ${ }^{8}$
3 Covil, A., Gurmeet C. (2013) Best Practices in Adopting a Shared Services Model, Avasant.

4 Struhar C. (2015) Five Characteristics of the Best Shared Service Centers

5 Covil, A., Gurmeet C. (2013) Best Practices in Adopting a Shared Services Model, Avasant.
6 Covil, A., Gurmeet C. (2013) Best Practices in Adopting a Shared Services Model, Avasant.

7 Deloitte (2011) Shared Service Hand Book - Hit the Road, Deloitte

8 Seal W., Herbert I. (2013) Shared Service Centers and the Role of the Finance Function: Advancing the Iron Cage?" Journal of Accounting \& Organizational Change, Vol. 9 Issue: 2, pp.188-205 
Relevant factors for a site location analysis (Deloitte, 2011) $)^{9}$ are socio-economic factors, tax and subsidiary factors, infrastructure factors, living environment factors, operational cost factors, office space factors, and labour factors.

According to the experience of different companies which established SSC or consultants for SSC, developing a robust shared services strategy is heavily dependent on systems and technology. SS Implementation includes: assessment, design and pilot project, implementation and roll-out, and optimization. (Covil and Gurmeet, 2013) ${ }^{10}$

After establishment of effective SSC all shareholders should take care of permanent improvement of processes and introducing new functions in SSC. Moreover, flexibility, leanness and scalability are needed for the company's survival (Ernst \& Young, 2013). ${ }^{11}$

According to the Chandok et al. survey $(2016)^{12}$ many companies in different industries are in the phase of exploring possibilities of creating digitalized SSC, and only about $22 \%$ of SS organizations in the research started activities connected to forming automatized SSC. Henkel GmbH is one of those companies which are leaders in SSC.

\section{METHODOLOGY}

The case study methodology is the basic methodology of the research. This research is based on the publicly announced information about SSC of Henkel GmbH, annual reports, presentations of CFO's on CFO forums (Khunert, 2013; Žepinić, 2014; Đukanović, 2017) and CFO interviews (Mackrodt, 2007; Jaeckle, 2012).

The period of analysis SSC is from 2003 to 2017, but EBIT margin (\%) indicator has been in the focus since 2010. The results will be compared to other relevant surveys for making final conclusions about Henkel's story. The limitations of analysis are numerous and varied, due to the fact that SSC is an internal transformation project of the company, and many pieces of information are not publicly announced. Different interviews of CFO's have partial information or general information without precise explanation and purpose.

\section{RESEARCH RESULTS}

Henkel is a privately owned company, established more than 140 years ago. Headquarter of the company is located in Dusseldorf, Germany. It is a globally operating organization, which performs business on 171 manufacturing sites around the world, with 3 basic business units: 1) Adhesive Technologies ( $48 \%$ of total sales), 2) Laundry and Home Care (31\% of total sales), 3) Beauty Care (20\% of total sales). Henkel is one of the most internationally represented German companies,

9 Deloitte (2011) Shared Service Hand Book - Hit the Road, Deloitte 10 Covil, A., Grumeet C. (2013) Best Practices in Adopting a Shared due to the fact that over $80 \%$ of its 52,000 employees are employed outside of Germany. Accordingly, $42 \%$ of their sales are generated in the emerging markets (Henkel, 2017).

Henkel's business used to be organized according to countries. In 1999, Henkel's management decided to change the business model and to organize business according to the business sector needs across countries. Having in mind that the Finance sector is a business provider, it means that Finance had to adjust to cross-country approach. They used to have 37 financial departments in all European countries, with different organization (i.e. none consists) and targets, and the final aim was to transform all of those organizations in one transactional finance organization. Henkel's decision was to create SSC, and their vision was to create world class Finance and Administration in 2003. It meant that all financial processes should be standardized - with adefined quality level, made easier, improved for better reporting and less-time consuming all over the group. The first step was to standardize and automate processes, but step by step. The second step was to centralize processes (for example one in the UK for subsidiaries in England and Ireland, one in France for 5 French subsidiaries, one in Scandinavia for 21 Northern Europe subsidiaries, and one in Germany for eight German subsidiaries, etc. ). An important thing was that the change management team created IT council, which was responsible for providing a common IT platform, and solving local IT issues in order to adjust it to the group standard. The third step was to move processes to SSC. It resulted with decreased costs in Finance and Accounting by $20 \%$ at the first quartile of introduction (early change management achievements are presented in Table 2).

According to Mackrodt (2008) all finance departments had best practices structures, but not end-to-end in the entire process and fully transparent cost structures. Accordingly, the starting points were to create change management team (project team, with 11 members) and to define detailed common efficiency targets/plans for improvement and achievement, and to monitor it on regular basis. Secondly, the common IT platform was important, based on SAP ERP system, was required (they used to have only 26 different IT platforms in Western Europe). It was a precondition for establishing a single process standard into which they could roll-in any company. Thirdly, the change management team introduced regular "Work-out" sessions. It used to be organized as a brainstorming session, where everyone had a possibility to think open and without limits, if I had the power and authorization to change anything, what would it be. Fourthly, the head of (cross-country) processes had been introduced and employees in daughter countries reported to them (in fixed line), rather than to local CFO. Cross-country head of processes were in charge of General

11 Ernst \& Young. (2013) Share services optimization - Evaluation to the next generation of shared services, Ernst \& Young.

12 Chandok, P., Chheda, H., Edlich, A. (2016) How shared-services organizations can prepare for a digital future, McKinsey. 
Accounting (GA), Controlling, Purchase-to-Pay (PTP), and Order-to-Cash (OTC) processes. Lastly, in order to create a whole new understanding of processes, the change management team introduced the head of finance function, instead of country CFO. It was important for establishing standardized processes across the group. Finally, cost allocation to the business was a control instrument for business improvement. Mackrodt (2007) stressed that service agreements between organizational parts of companies within the group were important for further cost decrease, improvement of the service quality and customers' satisfaction. It had an impact on structured interaction of Finance with business units (BU), and helped Finance to become equal partner with BU. It is important to notice, that changing and leading role of Finance was the key driver for implementation of SSC in Henkel, which is in accordance with the findings of Seal and Herbert (2013). ${ }^{13}$

Table 2. Defined and achieved benchmarks - overview at the end of 2007

\begin{tabular}{|c|c|c|c|c|c|c|c|}
\hline \multirow{2}{*}{$\begin{array}{c}\text { Defined } \\
\text { benchmarks } \\
\text { / achieved } \\
\text { results }\end{array}$} & \multicolumn{2}{|c|}{$\begin{array}{c}\text { General cost decrease } \\
\text { within the company (\%) }\end{array}$} & \multicolumn{2}{|c|}{$\begin{array}{l}\text { Cost decrease in Finance } \\
\text { and administration (\%) }\end{array}$} & \multicolumn{3}{|c|}{ Other relevant achievements } \\
\hline & $\begin{array}{l}\text { World-class } \\
\text { standard }\end{array}$ & Achieved & $\begin{array}{l}\text { world-class } \\
\text { standard }\end{array}$ & Achieved & $\begin{array}{c}\text { No of } \\
\text { finance units }\end{array}$ & $\begin{array}{l}\text { No of } \\
\text { IT platforms }\end{array}$ & $\begin{array}{c}\text { Changing role } \\
\text { of country } \\
\text { CFO }\end{array}$ \\
\hline 2007 & $25 \%$ & $20 \%$ & $\begin{array}{l}1 \% \text { of net } \\
\text { external sales }\end{array}$ & $\begin{array}{c}\text { Decrease from } \\
1.6 \% \text { to } 1.1 \% \\
\text { of net external } \\
\text { sales }\end{array}$ & $\begin{array}{l}\text { From } 37 \text { to } \\
8 \text { units in } \\
\text { Europe }\end{array}$ & $\begin{array}{l}\text { From } 26 \\
\text { different to } \\
1 \text { common } \\
\text { IT platform } \\
\text { (SAP) in } \\
\text { Western } \\
\text { Europe }\end{array}$ & $\begin{array}{c}\text { Country CFO } \\
\text { became head } \\
\text { of finance }\end{array}$ \\
\hline
\end{tabular}

Source: (Mackrodt, 2008)

Henkel's SSC journey and employee development is presented in table 3. It is important to emphasize that Henkel as a company adopts strategy for every 4 years. A Relevant Strategy for further development of SSC, was the strategy in place for 2012-2016, which promoted idea that Henkel had to be a global leader in brands and technology, and it was based on 4 pillars: globalize, outperform, inspire and simplify.
Pillar Simplify was in focus of CFO's and it covered cost efficiency, best-in-class process (quality) and a strong IT focus. SSC is a key enabler of this pillar (Henkel, 2015). It is important to emphasize that Henkel wanted to be an industry leader in SSC, and that Henkel introduced Shared Service Catalogue with all processes (20) and sub-processes (50) (Đukanović, 2017).

Table 3. SSC Journey and employee development

\begin{tabular}{|c|c|c|c|c|c|c|}
\hline \multirow{2}{*}{ Years } & \multirow{2}{*}{ SSC } & \multirow{2}{*}{ Area coverage } & \multirow{2}{*}{ Characteristic of SSC } & \multicolumn{3}{|c|}{ No of employees } \\
\hline & & & & SSC & Outsource & \\
\hline 2003 & Manilla & APAC \& NA & One dimensional SC & & & \\
\hline 2006 & \multirow{5}{*}{ Bratislava } & \multirow{5}{*}{ WE \& CEE } & & 40 & 0 & 40 \\
\hline 2007 & & & Multi-regional SSC & 160 & 0 & 160 \\
\hline 2008 & & & & 300 & 0 & 300 \\
\hline 2009 & & & & 410 & 0 & 410 \\
\hline 2010 & & & & 560 & 0 & 560 \\
\hline 2011 & Mexico City & LATAM & Multi-functional SS & 1000 & 1000 & 1000 \\
\hline 2012 & \multirow{2}{*}{$\begin{array}{c}\text { Bangalore - external part- } \\
\text { ner (Accenture) }\end{array}$} & & Hybrid SS model & 1406 & 90 & 1496 \\
\hline 2013 & & & $\begin{array}{c}\text { Integrated Business } \\
\text { Solutions }\end{array}$ & 1959 & 85 & 2044 \\
\hline 2014 & Cairo, Shanghai & MEA, Greater China & \multirow{2}{*}{ Global Footprint } & 2530 & 180 & 2710 \\
\hline $\begin{array}{l}2015 / \\
\text { Total }\end{array}$ & 6 & Global & & 2816 & 225 & 3041 \\
\hline
\end{tabular}

Source: (Đukanović, 2017)

13 Seal W., Herbert I. (2013) Shared Service Centers and the Role of the Finance Function: Advancing the Iron Cage?" Journal of Accounting \& Organizational Change, Vol. 9 Issue: 2, pp.188-205 
Having in mind that the long term Henkel's strategy for 2030 (Henkel, 2017) - Achieve more with less, is based on a long term goal to become 3 times more efficient (in terms of ecological footprint in the first place, and as result of that in financial manner), it will be important to determine SSC services achievements at the end of 2016 (Appendix 2).

It can be concluded that Henkel introduced organization structure of SSC in accordance with its own need. Generally, it can be concluded that Henkel had in mind some general trends for establishing SSC in terms of target functions, processes, IT platform and location (Covil and Gurmeet, 2013). ${ }^{14}$ It is evident that finance had a changing and leading role in implementing SSC, which is in line with Deloitte's survey in 2011. Finally, Bratislava represents the most important SSC for the whole Henkel group (Appendix 2). It is logical, due to the fact that the biggest number of daughter-companies is located in Europe, and primarily, this SSC services Europe.
At the end of 2016, Bratislava SSC - process GA and Finance Tax Group, had: 94 employees, who speak more than 10 languages, delivered more than 50 legal entities month and closing activities, maintained more than 30,000 active general ledger accounts, created and maintained more than $72,000 \mathrm{CO}$ objects on a global basis, produced an average of 4,500 T\&E reports per month, registered more than 200 VAT registrations in Europe, managed more than 150 bank accounts, and handled more than 200 licenses IC agreements (Đukanović, 2017).

Finally, a successful Henkel's SSC story is visible in financial indicators (table 4), especially EBIT margin in terms of cost-efficiency and customer satisfaction. It had an increasing trend in the analysed period. However, one should bear in mind that SSC is one of indicators, but not the only one, which had impact on EBIT margin.

Table 4. Henkel's key performance indicators in the period from 2010 to 2016 (in billion EUR, \%)

\begin{tabular}{|c|c|c|c|c|c|}
\hline Year & Sales & $\begin{array}{c}\text { Operating profit } \\
(\text { EBIT })\end{array}$ & $\begin{array}{l}\text { Adjusted operating } \\
\text { profit (EBIT) }\end{array}$ & $\begin{array}{l}\text { Return on sales } \\
\text { (EBIT) in } \%\end{array}$ & EBIT margin (\%) \\
\hline 2010 & 15,092 & 1,722 & 1,862 & 11.4 & 12.3 \\
\hline 2011 & 15,605 & 1,765 & 2,029 & 11.3 & 13.0 \\
\hline 2012 & 16,510 & 2,190 & 2,335 & 13.3 & 14.1 \\
\hline 2013 & 16,355 & 2,285 & 2,516 & 14.0 & 15.4 \\
\hline 2014 & 16,428 & 2,244 & 2,588 & 13.7 & 15.8 \\
\hline 2015 & 18,080 & 2,645 & 2,923 & 14.6 & 16.2 \\
\hline 2016 & 18,714 & 2,775 & 3,172 & 14.8 & 16.9 \\
\hline
\end{tabular}

Source: (Henkel, 2015-2017)

\section{CONCLUSION}

Henkel $\mathrm{GmbH}$ has a successful story in implementing SSC. At the beginning, the key successful factors for change management within the company were (Mackrodt, 2008): 1) a good corporate culture - very open, friendly, and secure for employees; 2) involvement of employees in every (small) step and decision. Clear goals were for all stakeholders. It was strongly supported by the executive board. Proactive communication in terms of motivation staff was in place (it is in accordance with a survey done by Van der Linde et al., 2006). ${ }^{15}$ It was a win-win situation for all: employees saved jobs, transparency and common understanding were drivers in the process, company improved profitability and kept a market position which is important for owners and managers. The quality of service was provided, and customers used to be satisfied.

14 Covil, A., Gurmeet C. (2013) Best Practices in Adopting a Shared Services Model, Avasant.
In a later phase, according to Khunert (2013) the key take-outs were: think big - there were more SSC options than you believed at start, moved fast - implemented carefully and step by step, didn't offshore your trash - fix immediately, pushed headquarter and local managers to embrace change, treat SSC colleagues as full team members and celebrate successes together.

Accordingly, the main hypothesis of the research is that SSC improved profitability of the company, which was confirmed by an increasing trend of EBIT margin. However, we should have in mind that SSC is one of indicators, but not the only one, which had an impact on EBIT margin.

Furthermore, Henkel GmbH will have new challenges with appliance of a new strategy for the period 2016-2020, in order to support their vision to create sustainable value. In accordance with it, four basic pillars for it are: drive growth, accelerate digitalization, increase agility and fund growth

15 Van der Linde T., Boessenkool A., Jooste C. (2006) Key Success Factors for the Management of a Shared Services Business Unit, ActaCommercil 2006, p. 198-212 
(Henkel, 2017). SSC will be determined by the accelerated digitalization, which means that processes in SSC will be digitalized, and it will have an impact on the number and quality of employees. However, the role of head of finance will be important in the future, due to the fact that innovative humans' way of thinking, involvement of qualitative factors in decision making, tailor-made approach to customer and human touch for understanding and support for incentive of team are required for a future development. In terms of Henkel's strategy, it can be said (Žepinić, 2014) that the role of head of finance is based on four pillars: risk management, business partnering and planning, cash flow and performance management, and HR management and development. In fact, head of finance is a chief "everything" officer.

This research paper was a part of the project "Advancing Serbia's Competitiveness in the Process of EU Accession", no. 47028, in the period 2011-2017, financed by the Serbian Ministry of Science and Technological Development.

\section{LITERATURE}

Accenture. (2015) Shared Services in Financial Services Industry: An Operating Model to Reach Strategic Goals

Chandok, P., Chheda, H., Edlich, A. (2016) How shared-services organizations can prepare for a digital future, McKinsey.

Covil, A., Gurmeet C. (2013) Best Practices in Adopting a Shared Services Model, Avasant.

Deloitte (2011) Shared Service Hand Book - Hit the Road, Deloitte

Đukanović, M. (2017) Henkel - GA in Shared Services, Presentation at FINIZ 2017 round table, Belgrade, May 17, 2017

Ernst \& Young. (2013) Share services optimization - Evaluation to the next generation of shared services, Ernst \& Young.
Henkel's site (2017) www.henkel.com, date of access 06/30/17

Henkel. (2011) Henkel's' Manilla Annual Report (2011),http:// annualreport2011.henkel.com/excellence-is-our-passion/ manila-philippines.html, date of access 06/30/17

Henkel. (2015) 2014 Annual Report, Henkel

Henkel.(2016) 2015 Annual Report, Henkel

Henkel. (2017) 2016 Annual Report, Henkel

Jaeckle J. (2012) Henkel Group: High-growth Central, FDE, http:// www.the-financedirector.com/ features/featurehenkel-joachim-jaeckle-high-growth-markets-shared-services/, date of access 06/30/17

Mackrodt C. (2008) We Have Created at Henkel One Common Way Worldwide How We Work in Finance, ZfCM Zeitschrift fur Controlling \& Management, Vol. 52, 5/2008, p. 220-224

Kuhnert M. (2013) Shared Services at Henkel, Presentation at the 2013 CFO Event in Frankfurt, February 6, 2013

PwC (2008) How to design a shared service centre that works

Seal W., Herbert I. (2013) Shared Service Centres and the Role of the Finance Function: Advancing the Iron Cage?" Journal of Accounting \& Organizational Change, Vol. 9 Issue: 2, pp.188-205

Searle P. (2013) What are Shared Services Best Practices? Chazey Partners

Struhar C. (2015) Five Characteristics of the Best Shared Service Centres,https://www.cebglobal.com/blogs/five-characteristics-of-the-best-shared-service-centers/, date of access 06/30/17

Van der Linde T., Boessenkool A., Jooste C. (2006) Key Success Factors for the Management of a Shared Services Business Unit, ActaCommercil 2006, p. 198-212

Žepinić S. (2014) CFO Role in Henkel, Presentation at the third CFO Forum in the Republic of Serbia in Aranđelovac, May 22,2014 
Appendix 1. Results of implemented SSC in 270 companies all over the world

\begin{tabular}{|c|c|c|c|}
\hline Finance & $\begin{array}{c}(\%, \text { currently } \\
\text { in SSC) }\end{array}$ & HR & $\begin{array}{c}\text { (\%, currently } \\
\text { in SS) }\end{array}$ \\
\hline Account payable & 84 & Payroll / time administration & 40 \\
\hline Fixed Assets & 72 & Workforce/employee data administration & 36 \\
\hline General Accounting & 72 & HRIS maintenance and support & 33 \\
\hline Travel and expense & 70 & Health and insurance benefits administration & 33 \\
\hline Cash application & 65 & HR reporting and workforce analytics & 31 \\
\hline Collections & 60 & Call centre & 31 \\
\hline Payroll & 58 & New hire/on boarding support & 30 \\
\hline Credit management & 53 & Pension and retirement benefit administration & 26 \\
\hline Billing & 52 & Recruitment administration & 25 \\
\hline Internal Financial Reporting & 51 & Employee relations and communications & 22 \\
\hline Cash Management & 51 & Organization and position management & 22 \\
\hline Cost accounting & 45 & Training design, development or delivery & 21 \\
\hline Tax reporting and analysis & 51 & Performance management administration & 21 \\
\hline Tax filling & 40 & Expatriate administration & 19 \\
\hline Value added tax & 39 & Skills and competency administration & 16 \\
\hline Treasury & 37 & Succession planning administration & 13 \\
\hline External financial reporting & 37 & & \\
\hline Legal compliance reporting & 34 & & \\
\hline Internal audit/compliance & 31 & & \\
\hline Financial planning and analysis & 24 & & \\
\hline Forecasting & 23 & & \\
\hline Budgeting & 23 & & \\
\hline
\end{tabular}

Source: (Deloitte, 2011)

Appendix 2. SSC service and portfolio at the end of 2016

What? Process

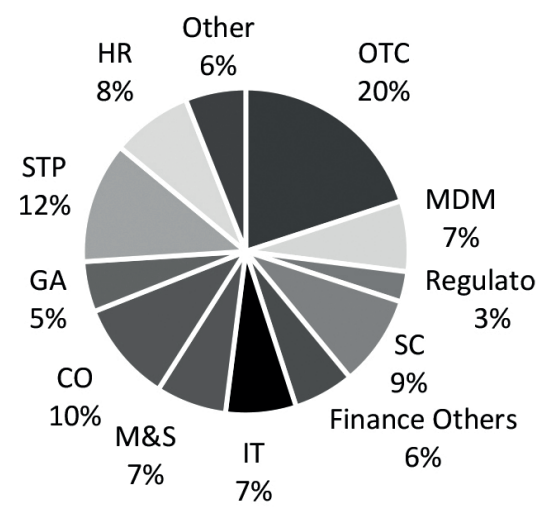

Where? SSC

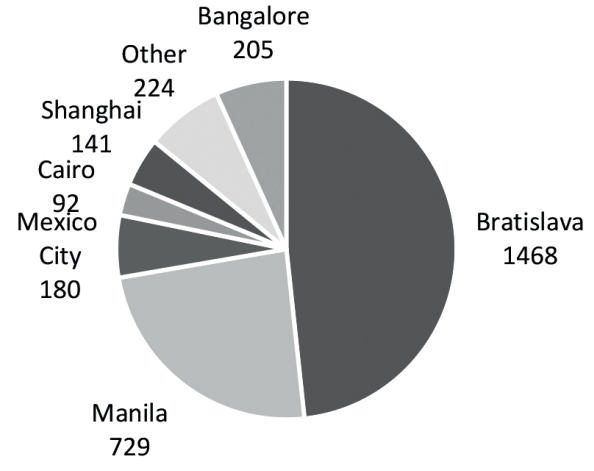

For whom? BU/Functions

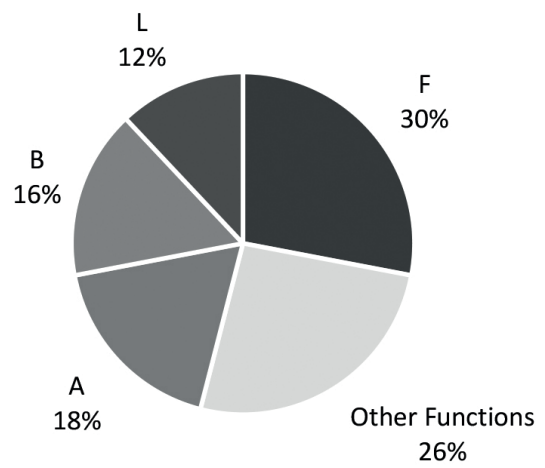

